\title{
Evaluation of a new mineral and trace metal supplement for use with synthetic diets
}

\author{
MARGARET S. LAWSON, BARBARA E. CLAYTON, H. T. DELVES, AND J. D. MITCHELL \\ From the Institute of Child Health, and The Hospital for Sick Children, London
}

SUMMARY In an earlier study (Alexander et al., 1974) it was shown that the mineral mixture used in association with a synthetic diet was deficient in zinc, copper, iron, and manganese. A new mixture containing appropriately increased amounts of these trace metals has now been evaluated by means of metabolic balance studies carried out on children with phenylketonuria. This new mixture was shown to be satisfactory for zinc, copper, and iron, but minor changes have been recommended for manganese.

Synthetic diets are used in infants and children for the treatment of inherited and acquired metabolic disorders. In a previous study (Alexander et al., 1974) using diets in which natural protein was replaced largely by amino acids, trace metals were provided from some natural foods and from a trace metal mixture, M1 (either Aminogran Mineral Mixture: Allen \& Hanbury Ltd., or Metabolic Mineral Mixture: Scientific Hospital Supplies Ltd., both of which had a similar composition). The results obtained from conventional metabolic balances indicated that these mixtures required the following modifications: a fourfold increase in the content of $\mathrm{Zn}$, a twofold increase in $\mathrm{Cu}$, and a $25 \%$ increase in $\mathrm{Fe}$. In addition, it was proposed that manganese (Mn) should be removed from the mixture. and provided separately at a dose of $1 \cdot 1 \mu \mathrm{mol}(60 \mu \mathrm{g}) / \mathrm{kg}$ per day. Adjustments were not recommended for any other components of the mixture. The object of the present study was to evaluate a new mineral mixture (M2) based on the above recommendations, using conventional balance techniques in patients with phenylketonuria (PKU).

\section{Patients}

Balances were performed on 7 children (Table 1) aged 23 days to 8.25 years receiving treatment for PKU with a controlled low phenylalanine diet in which a mixture of synthetic L-amino acids provided most of the protein requirements (Aminogran: Allen \& Hanbury Ltd.; for details see Bentovim et al., 1970; Smith et al., 1973). 5 of the patients were changed from M1 to M2 at least 4 weeks before the balances were performed, but Cases 1 and 2 had received M2 for only 9 and 8 days respectively before the studies began.

\section{Materials and methods}

The composition of the new mineral mixture M2 is given in Table 2 together with that of M1 for

Table 1 Details of the patients

\begin{tabular}{|c|c|c|c|c|c|}
\hline Case no. & Sex & $\begin{array}{l}\text { Age } \\
(y r)\end{array}$ & $\begin{array}{l}\text { Body weight } \\
(k g)\end{array}$ & $\begin{array}{l}\text { Period on } M 2 \\
\text { before study } \\
(w)\end{array}$ & Other clinical details \\
\hline $\begin{array}{l}1 \\
2 \\
3(a)^{*} \\
3(b) * \\
3(c) * \\
4 \\
5\end{array}$ & $\begin{array}{l}\mathbf{F} \\
\mathbf{M} \\
\mathbf{M} \\
\mathbf{M} \\
\mathbf{M} \\
\mathbf{M} \\
\mathbf{F}\end{array}$ & $\begin{array}{l}23 \mathrm{~d} \\
0 \cdot 25 \\
2 \cdot 08 \\
3 \cdot 33 \\
4 \cdot 92 \\
8 \cdot 0 \\
8 \cdot 25\end{array}$ & $\begin{array}{r}3 \cdot 8 \\
6 \cdot 0 \\
11 \cdot 5 \\
13 \cdot 0 \\
17 \cdot 5 \\
23 \cdot 2 \\
19 \cdot 6\end{array}$ & $\begin{array}{r}9 \mathrm{~d} \\
8 \mathrm{~d} \\
6 \\
6 \\
11 \\
4 \\
4\end{array}$ & $\begin{array}{l}\text { Detection of PKU at } 10 \mathrm{~d} \\
\text { Detection of PKU (atypical) at } 19 \mathrm{~d} \\
\text { Detection of PKU at } 8 \mathrm{~d} \text {; developing satisfactorily } \\
\text { Detection of PKU at } 5 \mathrm{~d} \text {; developing satisfactorily } \\
\text { Detection of PKU at } 8 \mathrm{w} \text {; developing satisfactorily } \\
\text { Diagnosis of PKU at } 2 \mathrm{y} \text {; IQ }<60 \\
\text { Diagnosis of PKU at } 1 \cdot 17 \mathrm{y} ; \mathrm{IQ} 83\end{array}$ \\
\hline
\end{tabular}

*Sibs; balances carried out at home. All other balances performed in hospital. 
comparison. The amount included in the diet was $1.5 \mathrm{~g} / \mathrm{kg}$ up to a maximum of $8 \mathrm{~g}$ daily. Manganese was given in the form of one tablet per $\mathrm{kg}$ body

Table 2 Composition of mineral and trace metal mixtures

\begin{tabular}{lll}
\hline & $\begin{array}{l}\text { Original formula }(\mathrm{Ml}) \\
(\text { per } \mathrm{kg})\end{array}$ & $\begin{array}{l}\text { Formula }(\mathrm{M2}) \\
(\text { per } \mathrm{kg})\end{array}$ \\
\hline Calcium & $2.05 \mathrm{~mol}(82 \mathrm{~g})$ & $2.05 \mathrm{~mol}(82 \mathrm{~g})$ \\
Potassium & $2 \cdot 12 \mathrm{~mol}(83 \mathrm{~g})$ & $2.12 \mathrm{~mol}(83 \mathrm{~g})$ \\
Sodium & $1.74 \mathrm{~mol}(40 \mathrm{~g})$ & $1.74 \mathrm{~mol}(40 \mathrm{~g})$ \\
Magnesium & $399 \mathrm{mmol}(9.7 \mathrm{~g})$ & $399 \mathrm{mmol}(9.7 \mathrm{~g})$ \\
Iron & $9.00 \mathrm{mmol}(550 \mathrm{mg})$ & $11.2 \mathrm{mmol}(628 \mathrm{mg})$ \\
Copper & $0.99 \mathrm{mmol}(63 \mathrm{mg})$ & $2.00 \mathrm{mmol}(127 \mathrm{mg})$ \\
Zinc & $1.84 \mathrm{mmol}(120 \mathrm{mg})$ & $7.34 \mathrm{mmol}(480 \mathrm{mg})$ \\
Manganesc & $1.04 \mathrm{mmol}(57 \mathrm{mg})$ & -60 \\
Iodine & $60.3 \mu \mathrm{mol}(7650 \mu \mathrm{g})$ & $60.3 \mu \mathrm{mol}(7650 \mu \mathrm{g})$ \\
Aluminium & $10.6 \mu \mathrm{mol}(285 \mu \mathrm{g})$ & $10.6 \mu \mathrm{mol}(285 \mu \mathrm{g})$ \\
Cobalt & $17.8 \mu \mathrm{mol}(1048 \mu \mathrm{g})$ & $17.8 \mu \mathrm{mol}(1048 \mu \mathrm{g})$ \\
Molybdenum & $20.7 \mu \mathrm{mol}(1981 \mu \mathrm{g})$ & $20.7 \mu \mathrm{mol}(1981 \mu \mathrm{g})$ \\
Phosphorus & $1.92 \mathrm{~mol}(60 \mathrm{~g})$ & $1.92 \mathrm{~mol}(60 \mathrm{~g})$ \\
\hline
\end{tabular}

* Manganese administered in tablets, each containing $1.4 \mu \mathrm{mol}$ $(75 \mu \mathrm{g})$.

Note: The above mixture was prepared from simple salts of the metals shown, i.e. chloride, sulphate and phosphate together with lactate as diluent. weight daily. Unfortunately, analysis of the tablets showed that each contained $1.4 \mu \mathrm{mol}(75 \mu \mathrm{g}) \mathrm{Mn}$ and not the $1 \cdot 1 \mu \mathrm{mol}(60 \mu \mathrm{g})$ that was recommended.

The collection of diets, faeces, and urine, preparation of samples for analysis, and analytical procedures used were as previously described (Alexander and Delves, 1972; Alexander et al., 1974). Analyses for $\mathrm{N}, \mathrm{P}$, and $\mathrm{Ca}$ were performed in addition to those for $\mathrm{Zn}, \mathrm{Cu}, \mathrm{Fe}$, and $\mathrm{Mn}$.

\section{Results}

Figs. 1, 3, 5, 7 show the total daily intake plotted against body weight, and Figs. 2, 4, 6, 8 show the daily intake per $\mathrm{kg}$ body weight plotted against daily excretion per $\mathrm{kg}$ body weight for the trace metals $\mathrm{Zn}, \mathrm{Cu}, \mathrm{Fe}$, and $\mathrm{Mn}$.

The mean values for daily intake, excretion, and absorption are given in Table 3, and in Table 4, the percentages of the daily intakes of $\mathrm{Zn}, \mathrm{Cu}, \mathrm{Fe}$, and $\mathrm{Mn}$ absorbed and retained by the patients are compared with results seen in healthy children on normal diets.

Table 3 Mean uptake and excretion of nutrients (units/kg per day $\pm S D$ )

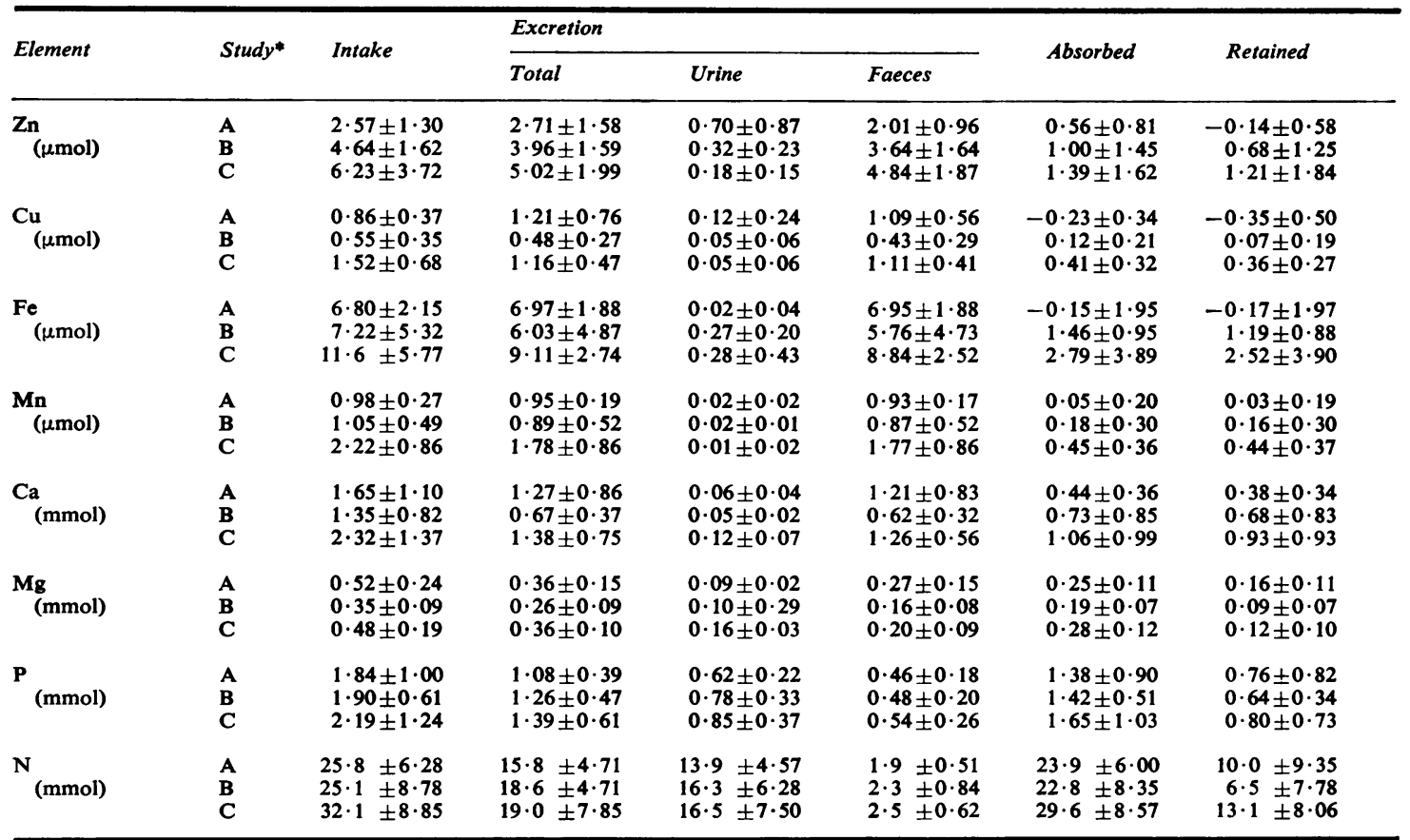

*A, Patients receiving synthetic diets

\} (Alexander et al., 1974).

C, Patients-this study.

Conversion: SI to traditional units-Zn: $1 \mu \mathrm{mol} \approx 65.4 \mu \mathrm{g} . \mathrm{Cu}: 1 \mu \mathrm{mol} \approx 63.5 \mu \mathrm{g}$. Fe: $1 \mu \mathrm{mol} \approx 55 \cdot 8 \mu \mathrm{g} . \mathrm{Mn}: 1 \mu \mathrm{mol} \approx 54 \cdot 9 \mu \mathrm{g}$. Ca: $1 \mathrm{mmol}$ $\approx 40.1 \mathrm{mg} . \mathrm{Mg}: 1 \mathrm{mmol} \approx 24.3 \mathrm{mg} . \mathrm{P:}: 1 \mathrm{mmol} \approx 31 \mathrm{mg} . \mathrm{N}: 1 \mathrm{mmol} \approx 14 \mathrm{mg}$. 
Table 4 Effect of increasing trace metal content of a synthetic diet on absorption and retention of the trace metals

\begin{tabular}{|c|c|c|c|c|c|c|c|c|}
\hline \multirow[b]{2}{*}{ Study* } & \multicolumn{2}{|l|}{ Zinc } & \multicolumn{2}{|l|}{ Iron } & \multicolumn{2}{|l|}{ Copper } & \multicolumn{2}{|c|}{ Manganese } \\
\hline & $\% A b s$ & $\%$ Ret & $\% A b s$ & $\%$ Ret & $\% A b s$ & $\%$ Ret & $\% A b s$ & $\%$ Ret \\
\hline $\begin{array}{l}\mathbf{A} \\
\mathbf{B} \\
\mathbf{C}\end{array}$ & $\begin{array}{l}15 \\
18 \\
13\end{array}$ & $\begin{array}{r}-7 \\
11 \\
11\end{array}$ & $\begin{array}{r}-6 \\
23 \\
18\end{array}$ & $\begin{array}{r}-6 \\
20 \\
16\end{array}$ & $\begin{array}{r}-30 \\
21 \\
27\end{array}$ & $\begin{array}{r}-40 \\
13 \\
24\end{array}$ & $\begin{array}{r}3 \\
20 \\
24\end{array}$ & $\begin{array}{r}1 \\
18 \\
22\end{array}$ \\
\hline
\end{tabular}

$\left.\begin{array}{l}\text { *A, Patients receiving synthetic diets and M1 } \\ \text { B, Healthy children receiving normal diets }\end{array}\right\}$ (Alexander et al., 1974).

C, Patients-this study.

$\%$ Abs, mean values for percentage absorption;

$\%$ Ret, mean values for percentage retention.

\section{Discussion}

These patients consumed a greater quantity of freely allowed natural foods, mainly fruit and vegetables, than those in the earlier study (Alexander et al., 1974; for details of diets in PKU, see Francis, 1975). Their daily intakes of $P$ and $\mathrm{Ca}$ were therefore higher (Table 3) even though the amounts of these macro-constitutents in M2 were not increased over those in M1.

The mean daily intakes of $\mathrm{Zn}$ and $\mathrm{Cu}$ were approximately those expected from the larger amounts of these metals in M2, but for Fe and Mn, the observed increases were greater than expected. This may be explained by the increased consumption of freely allowed foods, particularly by the older patients, which would have relatively little effect on

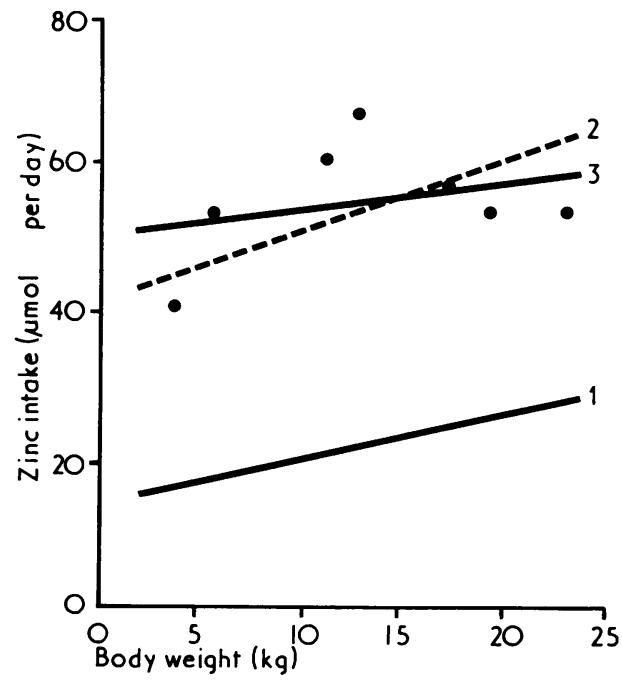

Fig. 1 Daily zinc intake v. weight. (1) Patients and (2) healthy children, from Alexander et al. (1974); (3) patients from this study. Conversion: SI to traditional units-Zinc: $1 \mu \mathrm{mol} / \mathrm{kg} \approx 65.4 \mu \mathrm{g} / \mathrm{kg}$. the total daily intakes of $\mathrm{Zn}$ and $\mathrm{Cu}$ because of their large increases, fourfold and twofold respectively, in M2. The consumption of larger quantities of natural foods would have a greater effect on the total intake of Fe, which was increased by only $25 \%$ in $\mathrm{M} 2$, and of $\mathrm{Mn}$ which was administered separately in tablet form at only the slightly higher dosage of $1.4 \mu \mathrm{mol}$ $(75 \mu \mathrm{g}) / \mathrm{kg}$ per day compared with the previous intake of $0.98 \mu \mathrm{mol}(54 \mu \mathrm{g}) / \mathrm{kg}$ per day (Alexander et al., 1974) provided by M1.

Zinc. The daily intake of $\mathrm{Zn}$ by the patients who received M2 closely matched that observed for the control children in the earlier study (Fig. 1) and ranged from 46 to $75 \mu \mathrm{mol}(3.0$ to $4.9 \mathrm{mg}) /$ day which is almost exactly the recommended intake for children of 46 to $77 \mu \mathrm{mol}(3.0$ to $5.0 \mathrm{mg}) /$ day (National Research Council, 1973). 6 of the 7 patients were in positive balance (Fig. 2) compared with only 3 out of 6 in the earlier study and the

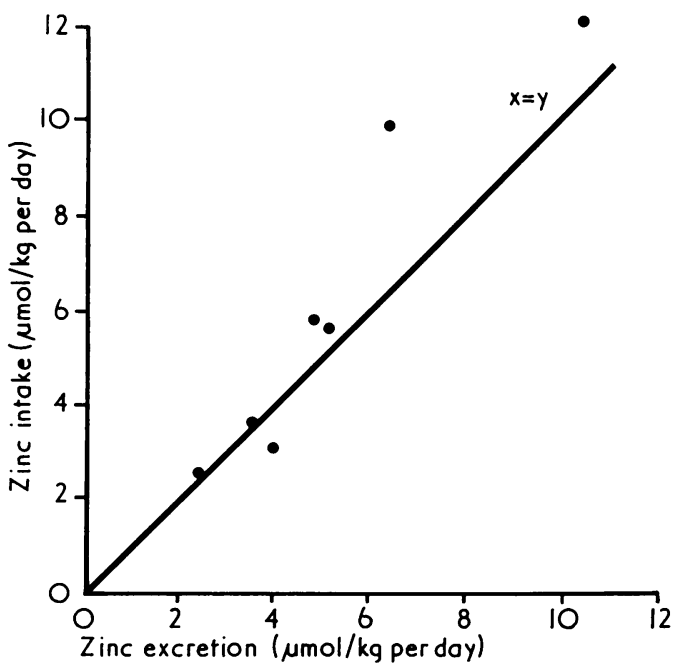

Fig. 2 Daily zinc balance. 


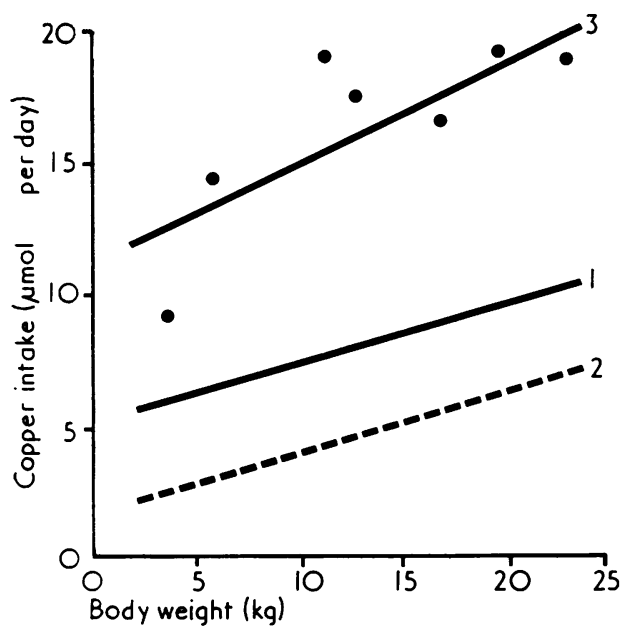

Fig. 3 Daily copper intake v. weight. (1) Patients and (2) healthy children, from Alexander et al. (1974); (3) patients from this study. Conversion: SI to traditional units-Copper: $1 \mu \mathrm{mol} / \mathrm{kg} \approx 63.5 \mu \mathrm{g} / \mathrm{kg}$.

percentages of the daily intake which were absorbed and retained by the patients were closer to those of the control children (Table 4).

Copper. The mean daily intake of copper by the patients receiving M2 was $1.5 \mu \mathrm{mol}(96 \mu \mathrm{g}) / \mathrm{kg}$ per day which is slightly in excess of the $0 \cdot 6-1 \cdot 2 \mu \mathrm{mol}$ $(40-80 \mu \mathrm{g}) / \mathrm{kg}$ per day recommended for children (WHO, 1973; National Research Council, 1973). All the patients were in positive balance (Fig. 4) com-

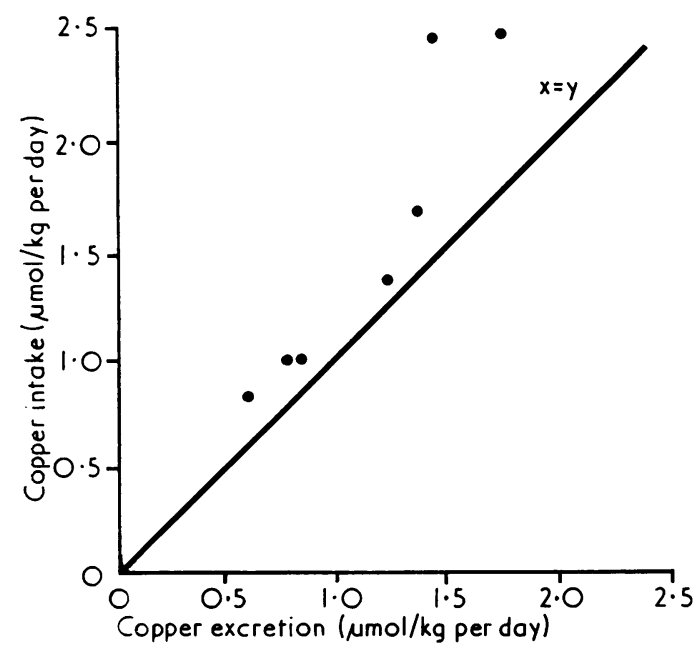

Fig. 4 Daily copper balance. pared with only 2 out of 6 in the earlier study and the percentages of dietary copper absorbed and retained were similar to those previously observed in control children (Table 4).

Iron. The daily intake of iron by the patients receiving M2 ranged from 78 to $167 \mu \mathrm{mol}(4 \cdot 38-$ $9 \cdot 35 \mathrm{mg}$ ). Though this is lower than the 179 to 269 $\mu \mathrm{mol}(10-15 \mathrm{mg})$ daily recommended for children (National Research Council, 1973), it encom-

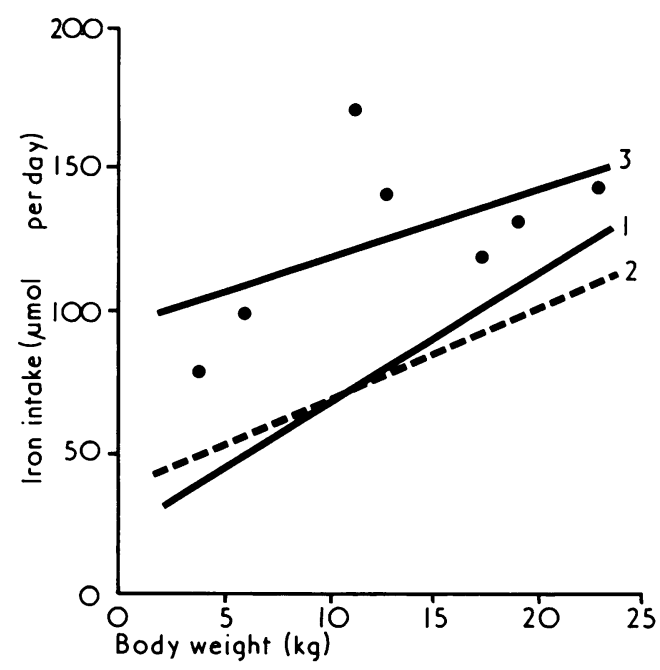

Fig. 5 Daily iron intake v. weight (1) Patients and (2) healthy children, from Alexander et al. (1974); (3) patients from this study. Conversion: SI to traditional units_Iron: $1 \mu \mathrm{mol} / \mathrm{kg} \approx 55 \cdot 8 \mu \mathrm{g} / \mathrm{kg}$.

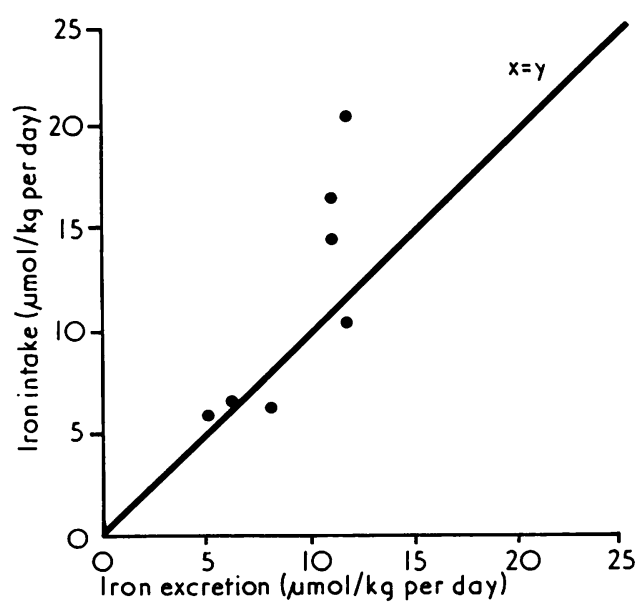

Fig. 6 Daily iron balance. 
passes the normal intake of $143 \mu \mathrm{mol} / \mathrm{day}(8 \mathrm{mg} /$ day) quoted by Macy (1942). 5 of the 7 patients receiving $\mathrm{M} 2$ were in positive balance for $\mathrm{Fe}$ (Fig. 6) compared with only 2 of the 6 patients who received M1 in the earlier study. The percentages of the intake absorbed and retained by the patients receiving M2 were closer to those observed in the control children than in the previous study (Table 4).

Manganese. Alexander et al. (1974) had recommended that the patients should receive $1 \cdot 1 \mu \mathrm{mol}$ $(60 \mu \mathrm{g}) / \mathrm{kg}$ per day of $\mathrm{Mn}$ from tablets each containing $1 \cdot 1 \mu \mathrm{mol}$. Owing to a manufacturing error each tablet contained $1.4 \mu \mathrm{mol}(75 \mu \mathrm{g})$ so that the patients received $1.4 \mu \mathrm{mol} / \mathrm{kg}$ per day. The 2 infants (Cases 1 and 2) who received only milk and Aminogran had dietary intakes of $1.37 \mu \mathrm{mol}$

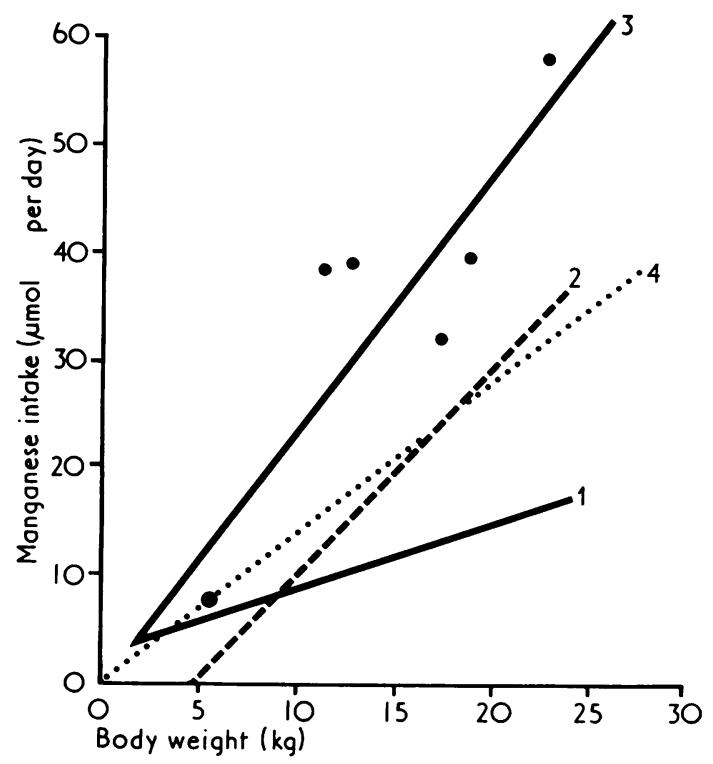

Fig. 7 Daily manganese intake v. weight. (1) Patients and (2) healthy children, from Alexander et al. (1974); (3) patients from this study; (4) $1.4 \mu \mathrm{mol} / \mathrm{kg}$ per day. Conversion: SI to traditional units-Manganese: $1 \mu \mathrm{mol} / \mathrm{kg} \approx 54.9 \mu \mathrm{g} / \mathrm{kg}$.

$(75 \cdot 2 \mu \mathrm{g}) / \mathrm{kg}$ per day and $1.41 \mu \mathrm{mol}(77 \cdot 4 \mu \mathrm{g}) / \mathrm{kg}$ per day (Fig. 7), which were close to the theoretical intakes from the tablets. The older children, however, had significantly greater intakes of 1.9-3.4 $\mu \mathrm{mol}(102-185 \mu \mathrm{g}) / \mathrm{kg}$ per day due to freely allowed natural foods, though the absolute amounts received by these patients of $5 \cdot 5-58 \mu \mathrm{mol}(0 \cdot 3-3 \cdot 2 \mathrm{mg})$ 124 hours is comparable with that observed for preadolescent girls of 38-87 $\mu \mathrm{mol}(2 \cdot 1-4 \cdot 8 \mathrm{mg}) / 24$ hours by Engel et al. (1967).
Six out of the 7 patients were in positive balance (Fig. 8) compared with only 3 out of 6 who received M1, and Table 4 shows that the percentages of the intake absorbed and retained by the patients receiving M2 were closer to those of the control children.

The recommended increases in the contents of $\mathrm{Zn}$, $\mathrm{Fe}, \mathrm{Cu}$, and $\mathrm{Mn}$ in the new trace metal supplement (M2) have therefore resulted in an overall improvement of the balance status of the patients for these metals. 6 out of 7 of the patients receiving M2 were in positive balance for all four metals (Figs. 2, 4, 6, 8) whereas in the earlier study of 6 patients who received M1, only 2 were in positive balance for $\mathrm{Fe}$ and $\mathrm{Cu}$, and only 3 for $\mathrm{Zn}$ and $\mathrm{Mn}$.

Although the percentages of the dietary intakes of $\mathrm{Zn}, \mathrm{Cu}, \mathrm{Fe}$, and $\mathrm{Mn}$ that were absorbed by the patients receiving M2 are now much closer to those previously observed for the healthy children, the absolute amounts absorbed and retained are higher due to the higher absolute intakes. The intakes were increased in order to produce positive retentions of these metals by the patients and this has been accomplished. There is therefore no indication that any further change should be made for $\mathrm{Zn}, \mathrm{Cu}$, and $\mathrm{Fe}$, though the long-term effects, if any, of greater than normal retentions of these metals will need to be kept under review.

In the case of Mn the intakes were much higher than expected and do not compare with our previous findings. This is due to the greater intake of natural foods by the present group of patients. It is

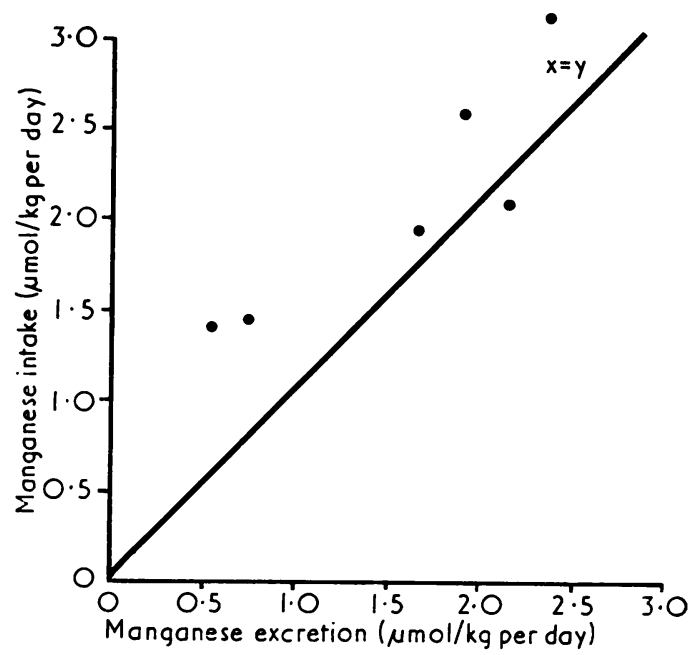

Fig. 8 Daily manganese balance. 
therefore recommended that $\mathrm{Mn}$ should be supplied in tablet form in an amount of $1 \cdot 1 \mu \mathrm{mol}(60 \mu \mathrm{g}) / \mathrm{kg}$ body weight daily up to a maximum of $6.6 \mu \mathrm{mol}$ $(360 \mu \mathrm{g})$. Alternatively, in order to avoid making the supplement more complex, this intake of $\mathrm{Mn}$ could be achieved by adding the Mn to the supplement at a concentration of $0.82 \mathrm{mmol}(45 \mathrm{mg}) / \mathrm{kg}$ of M2.

In view of this study and our earlier data (Alexander et al., 1974), it is likely that our patients being treated with the diet containing M1 were receiving deficient intakes of $\mathrm{Cu}, \mathrm{Mn}$, and $\mathrm{Fe}$, and especially of $\mathrm{Zn}$.

In a recent paper Lombeck et al. (1975) have shown reduced concentrations of serum selenium $(\mathrm{Se})$ in patients receiving synthetic diets for the treatment of PKU and maple syrup urine disease. Though Se is essential for animals, the requirement for this element in man is not known, but patients with kwashiorkor who had low serum Se levels had an increased weight gain when Se supplementation was given (Levine and Olson, 1970; Schwarz, 1965). Lombeck et al. (1975) emphasize the risk of deficiencies with synthetic diets and give this as an example.

In a collaborative study in the USA it was found that children with PKU were developing normally on treatment (Koch et al., 1973) and it was encouraging to see how closely the intellectual assessment approximated to that of the general population of 3 and 4 year olds. The patients did, however, appear to be slightly lower in intelligence than their normal sibs. There are many reasons why this should be, and nutritional deficiency is one possible contributory factor. In an early series of patients, Smith $e t$ al. (1973) observed a negative correlation between IQ and overt symptoms and signs of nutritional deficiency occurring in the first year of life. It is important that the intakes of mineral and trace metals in addition to phenylalanine and vitamins should be adequate. Until recently only limited information has been available on requirements for trace metals, and it is likely that their intake in synthetic diets has not been optimal.

Financial support from the Wellcome Trust, Allen \& Hanbury Ltd., and Unigate Foods Ltd. is gratefully acknowledged. The mineral mixtures were kindly provided by Dr. P. Woodings of Allen \& Hanbury Ltd. We are grateful to Professor O. H.
Wolff and Dr. Isobel Smith for permission to study their patients.

\section{References}

Alexander, F. W., and Delves, H. T. (1972). The preparation of a 'metal-free' nappy and its application to metabolic balances in children. Journal of Clinical Pathology, 25, 927-932.

Alexander, F. W., Clayton, B. E., and Delves, H. T. (1974). Mineral and trace-metal balances in children receiving normal and synthetic diets. Quarterly Journal of Medicine, 43, 89-111.

Bentovim, A., Clayton, B. E., Francis, D. E. M., Shepherd, J., and Wolff, O. H. (1970). Use of an aminoacid mixture in treatment of phenylketonuria. Archives of Disease in Childhood, 45, 640-650.

Engel, R. W., Price, N. O., and Miller, R. F. (1967). Copper, manganese, cobalt and molybdenum balance in preadolescent girls. Journal of Nutrition, 92, 197-204.

Francis, D. (1975). Diets for Sick Children, 3rd ed., p. 280. Blackwell, Oxford.

Koch, R., Dobson, J. C., Blaskovics, M., Williamson, M. L., Ernest, A. E., Friedman, E. G., and Parker, C. E. (1973). Collaborative study of children treated for phenylketonuria. Treatment of Inborn Errors of Metabolism, p. 3. Ed. by J. W. T. Seakins, R. A. Saunders, and $C$. Toothill. Churchill Livingstone, Edinburgh and London.

Levine, R. J., and Olson, R. E. (1970). Blood selenium in Thai children with protein-calorie malnutrition. Proceedings of the Society for Experimental Biology and Medicine, 134, 1030-1034.

Lombeck, I., Kasperek, K., Feinendegen, L. E., and Bremer, H. J. (1975). Serum-selenium concentrations in patients with maple-syrup-urine disease and phenylketonuria under dieto-therapy. Clinica Chimica Acta, 64, 57-61.

Macy, I. G. (1942). Nutrition and Chemical Growth in Childhood. Thomas, Springfield, Illinois.

Mills, C. F. (1974). The detection of trace element deficiency and excess in man and farm animals. Proceedings of the Nutrition Society, 33, 267-274.

National Research Council Food and Nutrition Board. (1973). Recommended Dietary Allowances, 8th revised ed. National Academy of Sciences, Washington.

Schwarz, K. (1965). Selenium and kwashiorkor. Lancet, 1, 1335-1336.

Smith, I., Lobascher, M., and Wolff, O. H. (1973). Factors influencing outcome in early treated phenylketonuria. Treatment of Inborn Errors of Metabolism, p. 41. Ed. by J. W. T. Seakins, R. A. Saunders, and C. Toothill. Churchill Livingstone, London.

World Health Organization (1973). Trace Elements in Human Nutrition. UN/WHO Technical Report Series, 532.

Correspondence to Prof. B. E. Clayton, Department of Chemical Pathology, The Hospital for Sick Children, Great Ormond Street, London WC1N $1 \mathrm{EH}$ 